\title{
Antifungal Effect of Flavonoid Extract of Trachyspermum Ammi Plant on the Gene Expression of Pro-inflammatory Cytokines such as IL-18 and TNF- $\alpha$ in Articular Chondrocyte Cells
}

\author{
Maryam Sadat Abtahi ${ }^{1}$, Zinat Mohammadi², Boshra Hatef ${ }^{*}$, \\ Masoomeh Amini ${ }^{4}$, Mehdi khorrami ${ }^{4}$ and Mohammad-Reza Aghanoori ${ }^{4}$
}

${ }^{1}$ Department of Department of Medicine, Baqiyatallah University of Medical Sciences, Tehran, Iran ${ }^{2}$ Department of Plant Physiology, Science and Research Branch Islamic Azad University, Tehran, Iran. ${ }^{3}$ Professor Assistant of Neuroscience Research Center of Baqiyatallah University of Medical Science, West Artesh Highway, Tehran, Iran.

${ }^{4}$ Department of Medical Genetics, Shiraz University of Medical Scienes, Shiraz, Iran.

DOI: http://dx.doi.org/10.13005/bbra/1876

(Received: 26 July 2015; accepted: 19 September 2015)

\begin{abstract}
The Trachyspermum ammi plant has anti-fungal properties. Some fungi such as a yeast two Sporothrix schenchii produces the arthritis in pack animals. The aim of this study is to examine the anti-fungal effects of this plant on the pro-inflammatory bio-markers, which are important in the course of fungal diseases. At first, the ethanol extract of the Trachyspermum ammi plant was provide by the Iranian biological resource center. We used chondrocyte cells as samples because they were similar to the cells with fungal infection. Then chondrocytes $\left(5 \times 10^{5}\right.$ cells/well) were incubated at a humidity of 90\%, 5\% CO2 and 37 ÚC for $72 \mathrm{~h}$ with control media alone or with Trachyspermum ammi at concentrations of $10 \mathrm{ig} / \mathrm{ml}$. One set of cells was activated for $1 \mathrm{~h}$ with mannose $(3 \mathrm{mg} /$ $\mathrm{ml}$ ) for both reverse-transcriptase PCR and real-time PCR analysis of Tumor necrosis factor alpha (TNF-á) and Interleukin-18 (IL-18) expression. The activated cells by mannose treated by the Trachyspermum ammi extract reduced TNF-á expression as activated cells by mannose with fluconazole. However the IL-18 gene expression was reduced by both treatments but fluconazole had better effect. Based on the PCR and Real-time PCR methods analysis of inflammatory gene expression, Trachyspermum ammi plant such as the flavonoids has noticeable anti-fungal properties on chondrocyte cells.
\end{abstract}

Key words: Trachyspermum ammi, fluconazole, chondrocyte cells, Anti-fungal Infection

\section{Background}

There are only 100 species between 200,000 to 50,000 fungal species that cause infectious diseases in humans (kobayashi, 1990). The one cause of Arthritis could be some fungi like sporotrichosis that is a couse of sporothrix schenchii. Fungal arthritis damages the bone of wrists and ankles, fingers, ribs and vertebrae

\footnotetext{
* To whom all correspondence should be addressed. Tel.: +982126127286; Fax: +982126127286

E-mail: boshrahatef@yahoo.com
}

following the release of cutaneous and subcutaneous lesions and causes the occurrence of fungus (rippon, 1988). The hospital infections increases the fungual disease (Kantarciohla \& Yucel, 2002). pathogen-associated molecular patterns (PAMPs) that are recognized by germ lineencoded proteins and pattern recognition receptors (PRRs), are present in different cells of the organism. Their presesnce is mainly seen in monocytes, macrophages, dendritic cells, B-cells, T-cells and endothelial cells. PRRs include the Tolllike receptors (TLRs), a protein family of cellular 
receptors that mediate recognition of microbial pathogens and subsequent inflammatory response in vertebrates (Latge', 2010 and Levitz, 2010). TLRs and other PRRs confer PAMP recognition and their signaling triggers synthesis followed by release of pro-inflammatory cytokines, and induces expression of co-stimulatory molecules for promoting activation of adaptive immunity during antigen presentation. The simultaneous activation of multiple PRRs by one fungal pathogen endows the immune system with a broad range of possibilities for a specific and effective immune response (Valent, 2002)

Interleukine-18 (IL-18) has a role in regulating the innate and acquired immune system and also plays a key role in auto-immune, inflammatory, infectious and fungal diseases (Harishan, 2007). Tumor necrosis factor alpha (TNFá) is a polytrophic factor which belongs to the cytokine family. TNF- $\alpha$ is a strong proinflammatory cytokine which belongs to the polypeptide group, which consists of several cytokines and growth factors (Carswell, 1975). Anti-fungal medications, with various formulas.. However sometimes they are unable to provide a cure or must be used for long periods of time which may result in the appearance of diverse side effects (Rippon, 1988 and kown-chung, 1992).

Trachyspermum ammi is a native of Egypt and is cultivated in Iraq, Iran, Afghanistan, Pakistan, and India(Prakash Nadda, 1999-2011), Trachyspermum ammi L. belongin to family Apiaceae is a highly valued medicinally important seed spice. Trachysper ammi, commonly referred as Bishop's weed, Carom seed (English names) and ajowani or omum in Indian languages (Wadicar et al, 2012). Ajwain seed analysis has revealed it to contain fiber (11.9\%), carbohydrates (38.6\%), tannins, glycosides, moisture $(8.9 \%)$, protein (15.4\%), fat (18.1\%), saponins, flavone and mineral matter (7.1\%) containing calcium, phosphorous, iron and nicotinic acid (Pruthi, 1992). Higher phenolic and flavonoids content showed high antioxidant activity in ajowani seed extract (Saxena et al, 2012). In general all the parts of this active ingredient are made up of fenols, which have both anti-oxidant and anti-microbe properties. Therefore it can be used as a preservative in food (bown, 1996). studies in Iran showed that the extract of this plant has better anti-fungal effects compared to anti-bacterial effects (khowje karam dini, 1988).

The aim of this study is to compare the effect of the Trachyspermum ammi plant and the common medication, fluconazole on chondrocyte cells. firstly the chondrocyte cells (Cartilageforming cells) were actived by using a suitable concentration of mannose and forcing the cell to produce infectious cytokines, which consist of IL18 and TNF-a, the effect of the Trachyspermum ammi plant on decreasing gene expression of the infectious intermediates is examined and compared with fluconazole.

\section{METHODS}

\section{Cultivating THP-1 Monocyte/Macrophage cells}

Articular chondrocytes were isolated from the radiocarpal joints of mature Holsteins by digestion of the tissue with typeII collagenase (220U/ml, GIBCO, USA) for 12-18 h at 37 ÚC. The isolated cells were filtered through a wire mesh screen to remove debris, and rinsed four times with Hank's Balanced Salt Solution (GIBCO, USA). Cells were pelleted by centrifugation and resuspended in control media containing: Dulbecco,s Modified Eagle Medium: Nutrient Mix F-12 (GIBCO, USA) supplemented with $10 \%$ fetal bovine serum (FBS, Invitrogen), $50 \mu \mathrm{g} / \mathrm{ml}$ ascorbic acid (GIBCO, USA), and $50 \mu \mathrm{g} / \mathrm{ml}$ gentamycin (GIBCO, USA). Chondrocyte were counted and assessed for viability using a hemacytometer and the Trypan blue exclusion method. Articular chondrocytes were plated in six-well plates (Costar; Cambridge, MA,USA) at a density of $5 \times 10^{5}$ cells/well and maintained at $37 \mathrm{U} C, 5 \% \mathrm{CO}_{2}$ for 5 days prior to use (Au B et al, 2007).

\section{Determining LC50 in THP-1 cells by using the Zenyan extract}

The ethanol extract of Tracyspermum ammi were prepared at concentrations of $10,20,30$, 40, 50, 60, 70, 80, 90 and $100 \mu g$ per $\mathrm{ml}$ and using the DMEMF-12 cultured environment. These concentrations were added to 12 pocketed flat bottom plates, which were kept in an incubator at a temperature of $37 \mathrm{C}, 5 \% \mathrm{Co}_{2}$ and $90 \%$ humidity. Thus LC50 has a concentration of $30 \mu \mathrm{g} / \mathrm{ml}$ and its average was calculated to be $15 \mu \mathrm{g} / \mathrm{ml}$ (Claude, 2005).

Expressing the Bovine TNF- $\alpha$, Bovine GAPDH, Bovine IL-18 genes by treating 
(chondrocyte cells) with mannose

After determining LC50, the ethanol extract at a consistency of $10 \mu \mathrm{g} / \mathrm{ml}$ was added. The plates were incubated at a temperature of $37^{\circ} \mathrm{C}$, $5 \% \mathrm{CO}_{2}$ and $90 \%$ humidity and a duration of 72 hours. At the end of this stage the cells were treated with a 3mg/ml (Astarie-Dequeker et al, 1999) concentration of mannose. They were then incubated at a temperature of $37^{\circ} \mathrm{C}, 5 \% \mathrm{CO}_{2}$, and $90 \%$ humidity and a duration of 1 hour in order to express the Bovine TNF- $\alpha$, Bovine GAPDH, Bovine IL-18 genes. Furthermore in the next stage of this experiment a $30 \mathrm{mg} / \mathrm{ml}$ concentration of fluconazole was added to plates containing monocyte and mannose. In order to measure the amount of gene expression the infected cytokines were kept in an incubator for 8 hours and under suitable conditions (Au B et al, 2007).

\section{Total RNA isolation}

The cells which were treated and controlled were collected in order to examine RNA. Total cellular Rna was isolated by lysing the cells with TRIzol reagent (Invitrogen) and extracted with chloroform (Sigma-Aldrich). Following vigorous agitation and a 3-min incubation at room temperature, the samples were centrifuges and the aqueous phase containing RNA was collected. The RNA was precipitated with isopropyl alcohol (GIBCO, USA) and resusupended in Rnease-free water. In order to work out the concentration of the RNA the electroforez gel agaroze $1 \%$ method was used (Au B et al, 2007).

\section{Complementary DNA synthesis}

For each sample, $1 \mu \mathrm{g}$ of total RNA was converted to complementary DNA (cDNA) using Moloney-Murine Leukemia Virus reverse transcriptase from the Advantage RT-for PCR kit (CinnaGen, IRAN). RT was carried out at $42^{\circ} \mathrm{C}$ for $60 \mathrm{~min}$ followed by heating at $94^{\circ} \mathrm{C}$ for $5 \mathrm{~min}$ to stop direction of the reaction of the cDNA synthesis reaction and to destroy any Dnase activity. Semiquantitative RT-PCR (Model Bio-Rad, Made in Thermo Cycler, USA) was performed using primers specific to Bovine TNF- $\alpha$ ( forward, TAA CAAGCC GGT AGC CCACG; reverse, GCAAGG GCT CTT GAT GGCAGA), Bovine IL-18 ( forward, AGACCT GGAACTAGATCACTTTGG; reverse, TTG TTC TCA CAG GAG AGA GTA GAC) and Bovine GAPDH ( forward, ATT CCA CCC ACG GCAAGT T; reverse, CGC TCC TGG AAG ATG
GTG AT ) as the housekeeping gene were aiso used (Takapouzist, IRAN ) using $2 \mu \mathrm{l}$ Cdna template and reagents from the SuperTaq Plus Kit (Takapouzist, IRAN). All the samples together were measured to be $25 \mu$ l. The samples were instantly put in the PCR, and the following standard program was used: 5 minutes separation of two strands at $95{ }^{\circ} \mathrm{C}, 45$ seconds of denaturation at a temperature of $95^{\circ} \mathrm{C}$ (this stage was repeated for 40 cycles), 45 seconds of connecting the primer to the sample strand at a temperature of $59^{\circ} \mathrm{C}, 30$ seconds of expanding the new strand at $72^{\circ} \mathrm{C}$ (this stage was repeated for 40 cycles), and infinite time at the final stage of strand expansion at a temperature of $72{ }^{\circ} \mathrm{C}$. In this way the genes that were needed for our investigation were cultivated (Au B.A et al, 2007).

\section{Quantity of Real-time PCR}

Real-time PCR was used with the primer sequences as it was mentioned earlier and kit evagreen from the Cinocolon company was used to bring about a Real-Time reaction.

In addition by using a standard program, which consisted of the primary stage: one cycle of denaturation for a duration of 15 minutes at a temperature of $95^{\circ} \mathrm{C}$, then the denaturation stage: denaturation for 15 seconds in 40 cycles at a temperature of $96^{\circ} \mathrm{C}$, then the connection stage: 60 seconds of connection in 40 cycles at a temperature of $60-65^{\circ} \mathrm{C}$, and finally the elongation stage: elongation for 20 seconds in 40 cycles at a temperature of $72^{\circ} \mathrm{C}$, the scale of specific mRNA for each gene was evaluated (Au B et al, 2007).

\section{Statistical tests}

After cultivating the chondrocyte cells in suitable conditions they were then treated in the following groups: chondrocyte cells without mannose (Cell group), chondrocyte cells accompanied with $3 \mathrm{mg} / \mathrm{ml}$ of mannose (Cell+ mannous group), chondrocyte cells accompanied with $3 \mathrm{mg} / \mathrm{ml}$ of mannose and $10 \mu \mathrm{g} / \mathrm{ml}$ of the ethanol extract of Trachyspermum ammi (Cell+ mannous+ extract group) and chondrocyte cells along with 3 $\mathrm{mg} / \mathrm{ml}$ of mannose, and $30 \mu \mathrm{g} / \mathrm{ml}$ of fluconazole chemical medication (Cell + Mannose + Fluconazole group). To compare groups, one-way ANOVA and bioferri were used because the distribution of variables was normal. The SPSS 21 was used and p-value under 0.05 was consider for significancy. 


\section{RESULTS}

The mean and SD of IL-18 and SD TNF-á cytokines are shown in the table 1.

The chondrocyte cells activated with 3 $\mathrm{mg} / \mathrm{ml}$ of mannose showed significantly a large scale of expression of the genes TNF and IL-18 in comparison with the control cells.

\section{The effect of Trachyspermum ammi on the gene expression of IL-18}

ANOVA test and Bonferroni analysis showed that both trachyspermum ammi and Fluconazole decreased the expression of the gene IL-18 to compare the mannous cells. between Cell+ mannous and Cell+ mannous+ extract: mean difference (95\% confidence interval was 2.6 (4.5 to

Table 1. Reperesents the mean (SD) of IL-18 and TNF- $\alpha$ in groups (Cell, Cell+Mannose, Cell+Mannose+Extract, Cell+Mannose+Fluconazole)

\begin{tabular}{lcccc}
\hline Cytokinins & $\begin{array}{c}\text { Cell } \\
(\mathrm{N}=8)\end{array}$ & $\begin{array}{c}\text { Cell + Mannose } \\
(\mathrm{N}=8)\end{array}$ & $\begin{array}{c}\text { Cell + Mannose }+ \\
\text { Extract }(\mathrm{N}=8)\end{array}$ & $\begin{array}{c}\text { Cell + Mannose + } \\
\text { Fluconazole (N=8) }\end{array}$ \\
\hline IL-18 & $22.52(1.2)$ & $29.56(1.3)$ & $26.9(1.4)$ & $24.05(1.1)$ \\
TNF- $\alpha$ & $22.72(0.83)$ & $36.25(0.7)$ & $25.29(1.2)$ & $25.54(1.3)$ \\
\hline
\end{tabular}

0.7) and P-value $=0.002$. between Cell + mannous and Cell+ mannous+ Fluconazole: mean difference (95\% confidence interval was 5.5 (3.6 to 7.3) and Pvalue was P-value $<0.0001$. But the Fluconazole showed better effect than extract: mean difference (95\% confidence interval was 2.8 (0.98 to 4.8 ) and $\mathrm{P}$-value $<0.002)$. the IL-18 was significantly lower than all groups expect Cell+ mannous+ Fluconazole group $(\mathrm{P}$-value $=0.158)$ (figure 1$)$.

The effect of Trachyspermum ammi on the gene expression of TNF- $\alpha$

ANOVA test and Bonferroni analysis showed that both trachyspermum ammi and

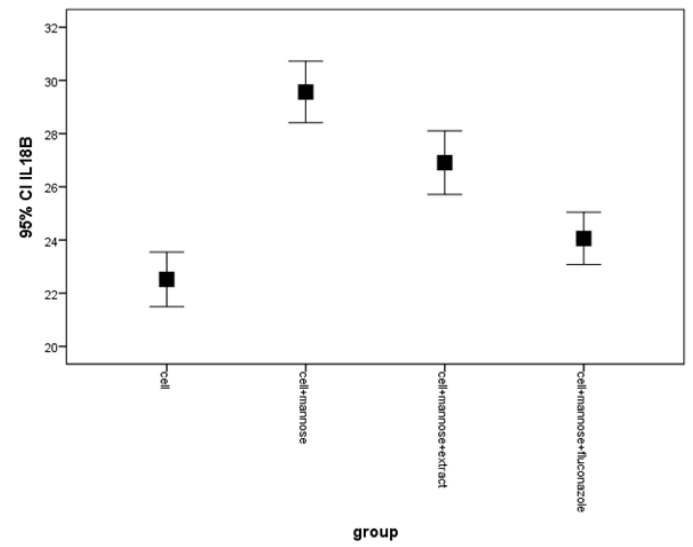

Fig. 1. Error plot showed the mean (SD) of IL-18 in all groups: There is significant Difference between groups (P value $<0.003$ ), but no significant difference between Cell + Mannose + Extract group and Cell + Mannose + Fluconazole.
Fluconazole decreased the expression of the gene TNF- $\alpha$ to compare the mannous cells. Bonferroni test showed that between Cell+ mannous and Cell+ mannous + extract: mean difference (95\% confidence interval was 10.9 (9.4 to 12.4 ) with Pvalue $<0.0001$, between Cell+ mannous and Cell+ mannous+ Fluconazole: mean difference (95\% confidence interval was 10.7 (9.2 to 12.2 ) with Pvalue $<0.0001$. But the Fluconazole showed no difference with extract: mean difference (95\% confidence interval was 0.25 (-1.2 to 1.7$)$ with $\mathrm{P}$ value $=1$. (figure 2).

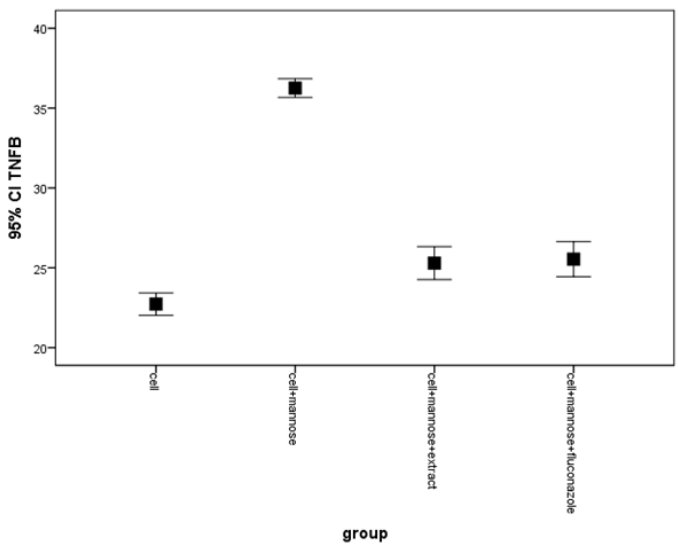

Fig. 2. Error plot showed the mean (SD) of TNF- $\alpha$ in all group: There is significant difference between groups (p-value $<0.001$ ), no significant difference between Cell + Mannose group and Cell+ Mannose + Fluconazole. 


\section{DISCUSSION}

In this study we have investigated the effects of the Trachyspermum ammi plant on Chondrocyte cells. It will be proven that the antifungal effects of the flavonoid extract of Trachyspermum ammi fights some of the effective pre-infectious gene expression of cytokines, IL-18 and TNF-á. Chondrocyte cells activated with mannose that is a common for infectious model. mannose exists in the fungi cell walls, starts off infectious replies in the tissues. Chondrocyte cells increase rapidly and produce an adequate amount of living cells for investigation. The Trachyspermum ammi extract can act as the main intermediary and as an anti-fungal factor.

In the present study, it has been proven that the Trachyspermum ammi plant extract suppresses the gene expression of IL-18 and TNFá in the chondrocyte cell which is cultivated and activated with mannose like as Fluconazole. But these treatment could not reach the suppresion level of gene expression like as Cell group expect Cell+ mannous+ Fluconazole group in IL-18 factor. However previous study showed that both treatment could suppress the gene expression of both inflammatory factors in monocyte cell like as cell group ( Abtahi et al, 2015)

The study of fungal infectious disease is perhaps a more challenging task than viral or bacterial diseases, because fungi are eukaryotic organisms and therefore immune system hardly distinguish them from the self-cells. On the other hand, the paradox is that most fungal diseases mainly affect individuals with impaired immune systems, such as after strong chemotherapy or bone marrow transplant patients, but not healthy ones. This puts fungal diseases somewhere between viral/ bacterial infectious diseases and cancer and autoimmune diseases (Kitano, 2007). Infectious arthritis is a common cause of joint destruction. The release of inflammatory mediators, joint and cartilage damage it, so that 48 hours after infection, the cells demolition begins(Robert et al, 1997).Various types of plants, ethanol and water extracts and essential oils have been successful in stopping the growth of fungi in experimental conditions (Refaei, 2001).

Iacobellis and its active partner, the antibacterial Trachyspermum ammi essence, were investigated via the Agar Diffusion method, and a high level of controlling effects were found. They controlled the growth of Rodotorula, Erwinia, Agrobacterium and Xanthomonas (Iacobellis et al, 2005).

Devasankaraiah, Singh, Rani, Srivastava, Navarro and their partners have also confirmed the anti-bacterial activity of the Trachyspermum ammi essence and have investigated its effects on several microbes resistant to medication (Navarro et al, 1996 and Devasanker et al, 1974,). Saksena and their partners have simet alilarly confirmed the anti-fungal activity of Trachyspermum ammi against the dermatophytes (Saksena, 1984). Likewise Pattanki and partners (Pattanki, 1996) and Ahmad and partners have carried out different investigations on the controlling effect of the Trachyspermum ammi essence on Candida albicans and have attested that the Trachyspermum ammi essence possesses this controlling effect (Ahmad, 2001).

In the present study, for the first time, the level of expression of pre-infectious cytokines was determined via mRNA. Moreover by adding a twofold or three-fold consistency of amphotericin B, the duration of cell division decreased and showed that it reduced from 69-72 hours to 24-36 hours. we attempted to isolate chondrocytes through separation a layer of cartilage cells without the addition of collagenase type II only three times with wash and put in a medium enriched with a cocktail of antibiotics.

The limitations of this study include a lack of in vivo experiments and using an animal serum that had a high probability of contamination. It is suggested that for future studies the effect of the extract on chondrocyte cells in vivo conditions and production of prostaglandins be investigated too..

\section{CONCLUSIONS}

The study showed that IL-18 and TNF- $\alpha$ expression were suppresed in mannose-activated chondrocyte cells treated by trachyspermum ammi plant like as fluconazole. Thymol is a phenol chemical compound which possesses anti-bacterial qualities and is used as an anti-fungal and an antiparasitic is suggested to investigation.

\section{Competing interests}


Authors declared that they had no competing interests'

\section{Authors' contributions}

Maryam sadat Abtahi carried out the molecular genetic studies, participated in the sequence alignment and drafted the manuscript and participated in the design of the study and participated in the sequence alignment . Dr. Boshra hatef performed the statistical analysis and revised the manuscript. All authors read and approved the final manuscript.

\section{ACKNOWLEDGEMENTS}

We would like to thank Zahra Mousavi khalkhali for native language revision of the manuscript.

\section{REFERENCES}

1. Abtahi, S.M., Hatef, B., Marashi, P., Vassaf, M. Antifungal effect of flavonoid extract of Trachyspermum ammi plant on the gene expression of pro-inflammatory cytokines such as IL-18 and TNF- $\alpha$ in articular THP-1 monocyte/macrophages cells. Biosciences, Biotechnology Research Asia. 2015; 12(2): 13411342.

2. Ahmad, I., Beg, AZ. Antimicrobial and phytochemical studies on 45 Indian medicinal plants against multi drug resistant human pathogens. J Ethnopharmacol 2001; 74: 11323.

3. Astarie-Dequeker, C., N`Diaye, Elsa-Noah., Le Cabec, V., G.Rittig, M., Prandi, J and Maridonneau-Parini, I. The mannose Receptor Mediates Uptake of Pathogenic and Nonpathogenic Mycobacteria and Bypasses Bactericidal Responses in Human Macrophages. Infection and Immunity. 1999; 67(2): 469.

4. Au B, A R Y., Al-Talib, B.A T. K., Au M, S A. Y., Phan, B. Sc P.V., Frondoza, Ph.D C.G. Avacoda soybean unsaponifiables (ASU) suppress TNFá, IL-1â, COX-2, Inos gene expression. and prostaglandin E2 and nitric oxide production in articular chondrocytes and monocyte/ macrophages. Osteoarthritis and Cartilage Journal. 2007; 15: 1250-1251.

5. Bown, D. The royal horticultural society encyclopedia herbs theiruses. London: Dorling Kindersley Distributed by Houghton Mifflin. 1996; 363-364.

6. Carswell, EA., Old, LJ., Kassel, RL., Green, S.,
Fiore, N., Williamson B. An endotoxin- induced serum factor that causes necrosis of tumors. Immunology. 1975; 72: 3666-3670.

7. Claude, E.B. LC50 calculations help predict toxicity . Global Aquaculture Advocate Journal. 2005; 84-87.

8. Devasankar, G., Hanin, I., Haranath, PS., Ramanamurthy, PS. Cholinomimetic effect of aqeous extract from Carum copticum seeds. $\mathrm{Br}$ J Pharmacol 1974, 52(4): 613-4.

9. Harishan Kar, M., Selvarai, P., Raieswari, DN., Anand, SP., Narayanan, PR. A promoter polymorphism of IL-18 gene in pulmonary tuberculosis in youth Indian population. Int $J$ Immunogenet. 2007; 34: 317-20.

10. Kitano, H. A robustness-based approach to systems-oriented drug design. Nat, Rev, Drug Discov. 2007; 5 (3): 202-210.

11. Kobayashi, GS. Fungi. In: Davis B.D, Dulbecco $\mathrm{R}$, et al. Microbiology. Philadelphia: Lippincott. 1990; 737-65

12. Kantarciohlu, AS., Yucel, A. The presence of fluconazole-resistant candida dubliniensis strain among candida albicans isolated from immunocompromised or otherwise debilitated HIV-negative Turkish patients. Rev Iberoam Mycol. 2002; 19 (1): 44-48.

13. Valent, J. Phytotherapy. treatment of disease by plants. Translated to Persian by: Emami A, Shams-Ardekani MR, Nekoei-naeini N. Tehran: Rahe-kamal Pub. 2002; 358-61.

14. Kown-chung, E., Bennett, JW. Medical Mycology. Lea and Febiger. Philadelphia. 1992; 158-71.

15. Rippon, JW. Medical: The Pathogenic Fungi and Pathogenic Actinomycetes. $2^{\text {nd }}$ ed. WB Saunders. Philadelphia. 1982; PP: 45-56.

16. Khowje Karam Dini, M., Rakhshandeh, H. The anti-bacterial and anti-fungal effects of the Zenyan extract compared with the effect of antibiotics. Sabzevar University of Medical Sciences, Asrar Publications. 1998; (7). (Persian)

17. Refaei, J. The effects of onion extract on lipase characteristics and growth pattern of Malassezia furfur. Presented for the M.Sc, Tehran, Tarbiat Modares University 2001. (Persian )

18. Iacobellis, NS., Lo, CP., Capasso, F., Senatore, F. Antibacterial activity of Cuminum cyminum L. and Carum carvi L. Essential oils. J Agric Food Chem 2005; 53(1): 57-61.

19. Navarro, V., Villarreal, ML., Royas, G. Antimicrobial evaluation of some plants used Mexican traditional medicine for the treatment of the infectios discases. $J$ Ethnopharmacol 1996; 53: 143-7. 
20. Saksena, NK., Saksena, S. Enhancement in the antifungal activity of some essential oils in Combination against some dermatophytes. Indian Perfumer 1984; 28(1): 42-5

21. Pattanki, S., Subramanyam, VR. Antibacterial and antifungal activity of ten essential oil in vitro. Microbios 1996; 86: 237-46.

22. Latge', J.P. Tasting the fungal cell wall. Cell Microbiol J. 2010; 12(7): 863-827.

23. Levitz, S.M. Innate recognition of fungal cell walls. PloS Pathog. 2010; 6(4): e1000758.

24. Parkash Nadda, J. Ayurvedic Pharmacopoeia of India. Government o India Ministry of Health and Family Welfare Department of Ayush. Part 1. 1999-2011; PP 170-1.
25. Waduicar, DD., Premavalli, K.S. Ajowan (Trachyspermum ammi) much: A shelf stable ready-to-eatappetizer, its development and storage. IFRG. 2012; 19(1): 321-325.

26. Pruthi, JS. Spices and Condiments. National Book Trust. $4^{\text {th }}$ ed. New Delhi. 1992.

27. Saxena, S.N., Agarwal, D., Saxena, R., Rathore, S.S. Analysis of anti-oxidant properties of ajwain (Trachyspermum ammi L) seed extract. International J. Seed Spices. 2012; 2(1): 50-55.

28. Robert W., 1ke: Bacterial arthritis. In koopman WJ: A Textbook of rheumatology, Arthritis and allied conditions 13 thed, Baltimore, william and wilkins, 1997; 2253-2287. 